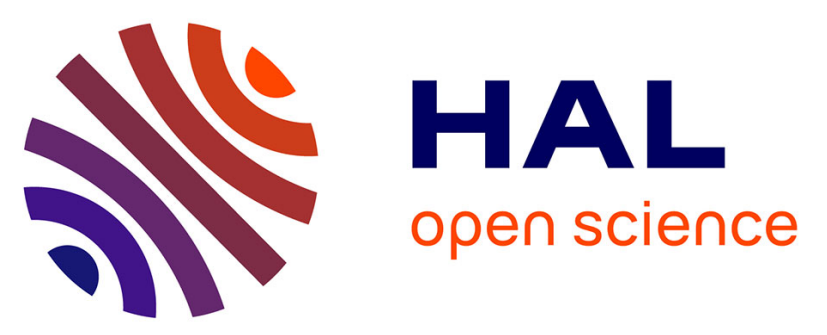

\title{
EVIDENCE OF PRIMARY EVENTS IN 20Ne, 22Ne FRAGMENTATION FROM COINCIDENCE MEASUREMENTS IN 20, 22Ne + 93Nb REACTION AT $30 \mathrm{MeV} / \mathrm{A}$
}

A. Chbihi, R. Billerey, B. Chambon, A. Chevarier, N. Chevarier, B. Cheynis, D. Drain, C. Pastor, M. Stern, A. Dauchy, et al.

\section{To cite this version:}

A. Chbihi, R. Billerey, B. Chambon, A. Chevarier, N. Chevarier, et al.. EVIDENCE OF PRIMARY EVENTS IN 20Ne, 22Ne FRAGMENTATION FROM COINCIDENCE MEASUREMENTS IN 20, $22 \mathrm{Ne}+93 \mathrm{Nb} \mathrm{REACTION}$ AT $30 \mathrm{MeV} / \mathrm{A}$. International Conference on Heavy Ion $\mathrm{Nu}-$ clear Collisions in the Fermi Energy Domain, Hicofed 86, 1986, Caen, France. pp.C4-87-C4-90, 10.1051/jphyscol:1986409 . jpa-00225772

HAL Id: jpa-00225772

https://hal.science/jpa-00225772

Submitted on 1 Jan 1986

HAL is a multi-disciplinary open access archive for the deposit and dissemination of scientific research documents, whether they are published or not. The documents may come from teaching and research institutions in France or abroad, or from public or private research centers.
L'archive ouverte pluridisciplinaire HAL, est destinée au dépôt et à la diffusion de documents scientifiques de niveau recherche, publiés ou non, émanant des établissements d'enseignement et de recherche français ou étrangers, des laboratoires publics ou privés. 
EVIDENCE OF PRIMARY EVENTS IN ${ }^{20} \mathrm{Ne},{ }^{22} \mathrm{Ne}$ FRAGMENTATION FROM COINCIDENCE MEASUREMENTS IN $20,22 \mathrm{Ne}+93 \mathrm{Nb}$ REACTION AT $30 \mathrm{MeV} / \mathrm{A}$

\author{
A. CHBIHI, R. BILLEREY, B. CHAMBON, A. CHEVARIER, N. CHEVARIER, \\ B. CHEYNIS, D. DRAIN, C. PASTOR, M. STERN, A. DAUCHY*, \\ C. MORAND*, A. GIORNI*, J. ALARJA*, J.L. CHARVET**, M. MORJEAN**, \\ S. JOLY* $Y^{*}, Y$. PATIN $^{*}, Y$, PRANAL * $^{*}$ L. SINOPOLI** and \\ J.L. UZUREAU** \\ Institut de Physique Nucléaire (et IN2P3), Université claude \\ Bernard, Lyon-I, 43 Boulevard du 11 novembre 1918, \\ F-69622 Villeurbanne Cedex, France \\ - Institut des Sciences Nucléaires de Grenoble, (IN2P3-USTMG), \\ 53. Avenue des Martyrs, F-38041 Grenoble, France \\ " C.E.A. Bruyères-le-Châtel, Service P2N, BP 12, \\ F-91680 Bruyères-le-Châtel, France
}

\begin{abstract}
Résumé - La compétition entre différents processus primaires de réaction est mise en évidence par l'étude des coīncidences particules léqères-fragment du projectile dans les réactions induites par les projectiles ${ }^{20} \mathrm{Ne}$ et ${ }^{2}{ }^{2} \mathrm{Ne}$ sur ${ }^{93} \mathrm{Nb}$ à $30 \mathrm{MeV} / \mathrm{A}$. La structure du projectile joue un rôle important dans la compétition entre les mécanismes de pick-up, stripping et break-up.
\end{abstract}

\begin{abstract}
Evidence that primary ejectiles formation strongly depends on the projectile structure is given by comparison of ${ }^{20} \mathrm{Ne}+{ }^{3} \mathrm{Nb}$ and ${ }^{22} \mathrm{Ne}+{ }^{93} \mathrm{Nb}$ reactions at $30 \mathrm{MeV} / \mathrm{A}$. Pick-up, stripping, break-up mechanism are identified using light particles-projectile fragments coincidence measurements.
\end{abstract}

\title{
I - INTRODUCTION
}

Nuclear reaction involving excited states of the reaction fragments can generally be subdivised into the primary process and the subsequent deexcitation through light particles emission or fission. The mechanisms of transfer and break-up in ${ }^{20} \mathrm{Ne}$ induced reaction have been studied for the system ${ }^{20} \mathrm{Ne}+{ }^{197} \mathrm{Au}[1]$ and ${ }^{20} \mathrm{Ne}+{ }^{27} \mathrm{Al}$ [2] at bombarding energies up to $20 \mathrm{MeV} / \mathrm{A}$ respectively. Therefore in order to check the relative importance of different dissociation phenomena, we studied the two reactions ${ }^{20} \mathrm{Ne}+{ }^{93} \mathrm{Nb}$ and ${ }^{22} \mathrm{Ne}+{ }^{3} \mathrm{Nb}$ at $30 \mathrm{MeV} / \mathrm{A}$.

\section{II - EXPERIMENTAL}

We performed on SARA coïncidence measurements between projectile like fragments and light particles. Mass identification and energy measurements of fragments are performed using two telescopes in the range 6 to 15 degrees. In fragment coincidence measurements the fragment telescopes were set at $8.5^{\circ}$. The light particle $(p, d, t, \alpha)$ are detected in a 5 to 35 degrees angular range using either a telescope (300 $\mu \mathrm{m}$ Si detected $+\mathrm{BaF}_{2}$ scintillator) or phoswich systems.

\section{III - COINCIDENCE MEASUREMENTS ANALYSIS}

When compared to ${ }^{20} \mathrm{Ne}$ results the mean feature to underline on ${ }^{22} \mathrm{Ne}$ fragmentation is the large amount of ${ }^{15} \mathrm{~N}$ and ${ }^{11_{B}}$ isotope production and the observation of sodium isotopes. The coincidences measurements on the two systems allow to understand most of 
the observed features. The relative yield for proton and alpha coincidence with projectile like fragments is given on figure 1.

Let us first concentrate on ${ }^{20} \mathrm{Ne}$ induced reaction. The deexcitation of the ${ }^{20} \mathrm{Ne}^{*}$ quasi projectile occurs preferentially through $\alpha$ emission by break-up mechanism or sequential decay. The signature of the two processes are given on figure 2. From their representation in the $E_{1 i}-E_{\alpha}$ plane it can be recognized in figure $2 a$ that for $\left[{ }^{16} \mathrm{O}, \alpha\right]$ events roughly one half of the strength is concentrated in a sharp peak which is, within the experimental resolution, consistent with zero energy transfer to the target nucleus. The other events are spread out over $50 \mathrm{MeV}$ excitation energy range. In figure $\mathbf{2 b}$ the correlation geometry allows to select events corresponding of deexcitations of ${ }^{2} \mathrm{Ne}^{*}$ through $\alpha$ emission. This deexcitation explains most of the ${ }^{16} \mathrm{O}$ and ${ }^{12} \mathrm{C}$ cross section observed. During the first step interaction between target and projectile a proton or [proton + neutron] transfer can occur. The so obtained ${ }^{19} \mathrm{~F}$ or ${ }^{18} \mathrm{~F}$ quasi projectile deexcite very easily by $\alpha$ emission such experimental decay leads to most of observed nitrogen and boron cross section. Similar analysis is performed concerning ${ }^{22} \mathrm{Ne}$ interaction. The deexcitation of ${ }^{22} \mathrm{Ne}^{*}$ quasi projectile is not the dominant process. However ${ }^{18} \mathrm{O}, \alpha$ coïncidence allows to put in evidence pure break-up mechanism. The competition with ${ }^{2}{ }^{1} \mathrm{Ne}^{*}$ and ${ }^{20}{ }^{0} \mathrm{Ne}{ }^{*}$ primary events can be estimated from the ratio of coincidence yields between ${ }^{16} \mathrm{O}-\alpha /{ }^{17} \mathrm{O}-\alpha /{ }^{18} \mathrm{O}-\alpha$ or ${ }^{12} \mathrm{C}-\alpha /{ }^{13} \mathrm{C}-\alpha /{ }^{14} \mathrm{C}-\alpha$ they are in the ratio $3 / 1.8 / 1$. Furthermore the most interesting feature is the formation of ${ }^{23} \mathrm{Na}^{*}$ through pick-up reaction $(Q=+2.75 \mathrm{MeV})$. The signature for such process is given by the ${ }^{19} \mathrm{~F}-\alpha$ coincidence. The sequential decay of ${ }^{23} \mathrm{Na} *$ leads to extra amoant of $\alpha$-coincidence with fluor, nitrogen, boron isotopes. When looking at ${ }^{15} \mathrm{~N}$ exclusive energy spectra deduced from $\alpha-{ }^{15} N$ correlation, one can extract two components corresponding respectively to a mean value $E_{1}=400 \mathrm{MeV}$ which can be reproduced assuming an optimum $Q$ value for pick-up process [3] and a constant fragment velocity during the following decay. The high energy component corresponds to a mean value $E_{2}=440 \mathrm{MeV}$ which can be calculated assuming an optimum $Q$ value corresponding to stripping process (figure 3). Similar results are obtained from. ${ }^{11} \mathrm{~B}-\alpha$-coinncidence

The formation of ${ }^{23} \mathrm{Na}$ is also corroborated by fragments-fragments correlation which at (8.5-8.5) degree shows typical ${ }^{11_{B}}{ }^{12} \mathrm{C}$ coinncidence. The energy distribution of both fragments is very narrow and the sum energy $E\left({ }^{12} \mathrm{C}\right)+E\left({ }^{11} \mathrm{~B}\right)=630 \mathrm{MeV}$ is very close to the incident one (figure 4). The missing energy corresponds to the $Q$ value for fragmentation. However such interesting feature corresponds to a very small yield (less than 10\%) compared to ${ }^{11} B-\alpha$ coîncidence.

\section{IV - CONCLUSION}

The comparison of the two entrance channel ${ }^{20} \mathrm{Ne}$ and ${ }^{22} \mathrm{Ne}$ allows to put in evidence that the primary events are strongly dependent upon the projectile structure. These first reaction steps are determinant in the isotope yields of projectile fragments even taking in account the sequential decay.

\section{REFERENCES}

[1] WALD, S. et al., Phys. Rev., C-22 (1985) 894

[2] OST, R. et al., Phys. Rev., C-32 (1985) 1927

[3] MERMAZ, M.C. et al., Nucl. Phys., A-441 (1985) 129 

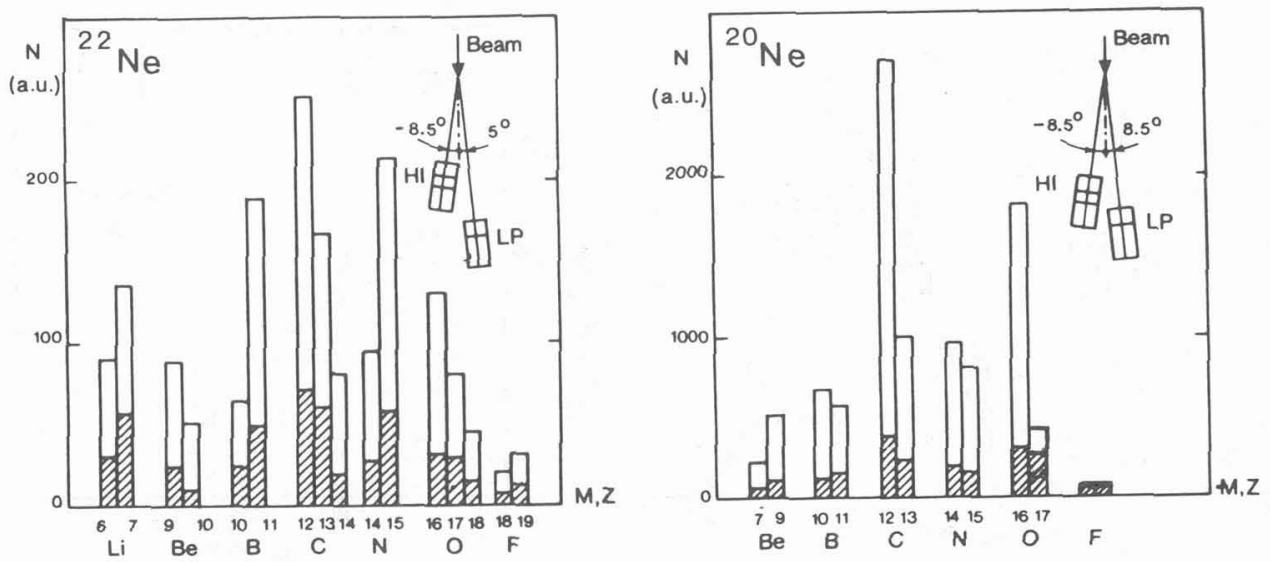

Figure 1 - The relative yield of proton (dashed areal and alpha (total areal coincidence plotted as function of ejectile mass in ${ }^{22} \mathrm{Ne}$ and ${ }^{20} \mathrm{Ne}$ induced reaction.

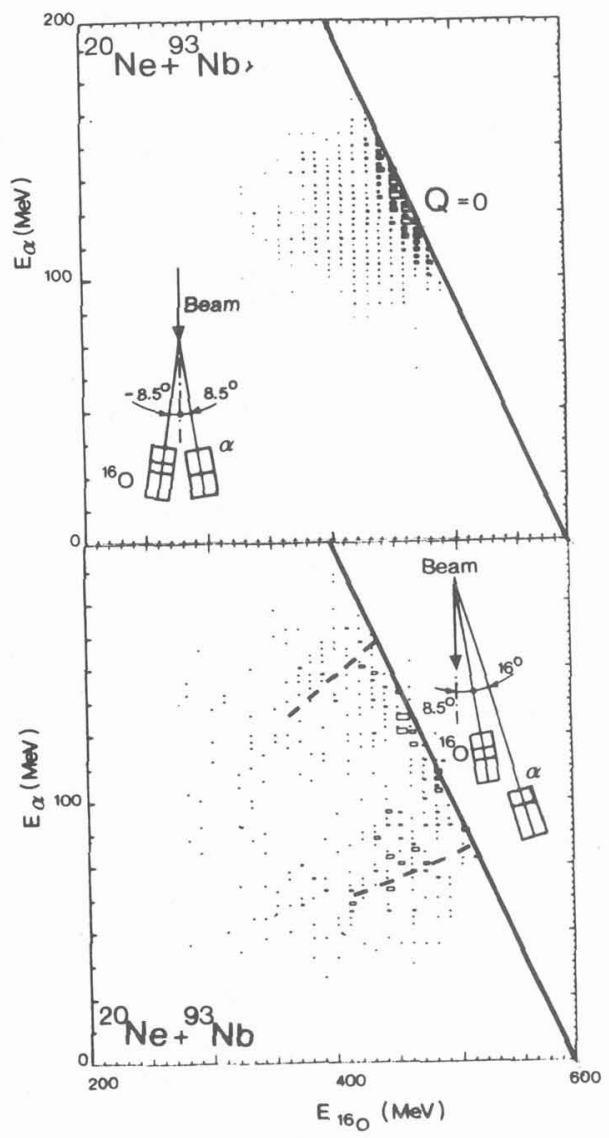

Figure 2 - Distribution of events in the $E_{H I}-E_{\alpha}$ plane.

In figure $2 a$ the solid lines mark the border consistent with zero energy transfer to the target $1 Q=01$. In figure $2 b$ the two dashed lines represent the mean value given by theoretical calculation for a statistical alpha emission from ${ }^{20} \mathrm{Ne}$. 


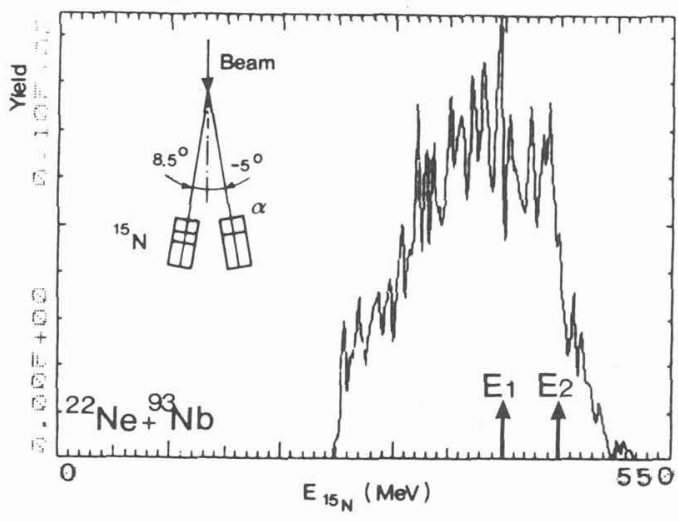

Fiqure 3 - Energy spectra of the ${ }^{15} \mathrm{~N}$ projectile like fragment in coincidence with $\alpha$ particles. $E_{1}$ and $E_{2}$ are the mean energy value of the two observed components.

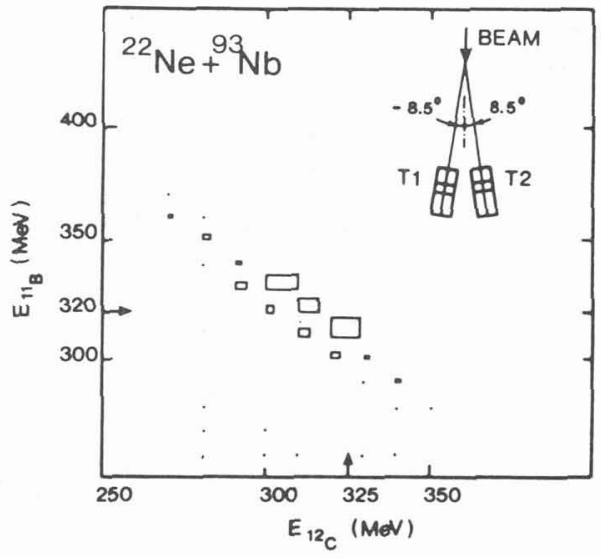

Figute 4 - Distribution of events in $E_{H-}-E_{H}$ plane in case of ${ }^{11} B,{ }^{12} \mathrm{C}$ coincidence measurements in ${ }^{22} \mathrm{Ne}+{ }^{93} \mathrm{Nb}$ reaction. 